\title{
Front Matter: Volume 9377
}

, "Front Matter: Volume 9377," Proc. SPIE 9377, Advances in Photonics of Quantum Computing, Memory, and Communication VIII, 937701 (17 April 2015); doi: $10.1117 / 12.2192016$

SPIE. Event: SPIE OPTO, 2015, San Francisco, California, United States 


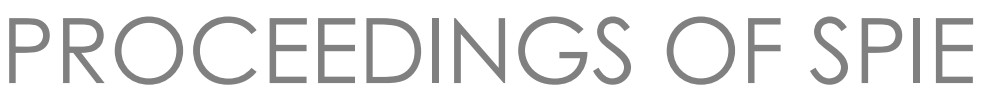

\section{Advances in Photonics of Quantum Computing, Memory, and Communication VIII}

Zameer U. Hasan

Philip R. Hemmer

Hwang Lee

Alan L. Migdall

Editors

10-12 February 2015

San Francisco, California, United States

Sponsored and Published by

SPIE 
The papers included in this volume were part of the technical conference cited on the cover and title page. Papers were selected and subject to review by the editors and conference program committee. Some conference presentations may not be available for publication. The papers published in these proceedings reflect the work and thoughts of the authors and are published herein as submitted. The publisher is not responsible for the validity of the information or for any outcomes resulting from reliance thereon.

Please use the following format to cite material from this book:

Author(s), "Title of Paper," in Advances in Photonics of Quantum Computing, Memory, and Communication VIII, edited by Zameer U. Hasan, Philip R. Hemmer, Hwang Lee, Alan L. Migdall, Proceedings of SPIE Vol. 9377 (SPIE, Bellingham, WA, 2015) Article CID Number.

ISSN: 0277-786X

ISBN: 9781628414677

Published by

SPIE

P.O. Box 10, Bellingham, Washington 98227-0010 USA

Telephone +1 3606763290 (Pacific Time) · Fax +1 3606471445

SPIE.org

Copyright (@ 2015, Society of Photo-Optical Instrumentation Engineers.

Copying of material in this book for internal or personal use, or for the internal or personal use of specific clients, beyond the fair use provisions granted by the U.S. Copyright Law is authorized by SPIE subject to payment of copying fees. The Transactional Reporting Service base fee for this volume is $\$ 18.00$ per article (or portion thereof), which should be paid directly to the Copyright Clearance Center (CCC), 222 Rosewood Drive, Danvers, MA 01923. Payment may also be made electronically through CCC Online at copyright.com. Other copying for republication, resale, advertising or promotion, or any form of systematic or multiple reproduction of any material in this book is prohibited except with permission in writing from the publisher. The CCC fee code is 0277-786X/15/\$18.00.

Printed in the United States of America.

Publication of record for individual papers is online in the SPIE Digital Library.

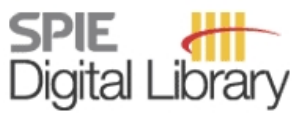

SPIEDigitalLibrary.org

Paper Numbering: Proceedings of SPIE follow an e-First publication model, with papers published first online and then in print. Papers are published as they are submitted and meet publication criteria. A unique citation identifier (CID) number is assigned to each article at the time of the first publication. Utilization of CIDs allows articles to be fully citable as soon as they are published online, and connects the same identifier to all online, print, and electronic versions of the publication. SPIE uses a six-digit CID article numbering system in which:

- The first four digits correspond to the SPIE volume number.

- The last two digits indicate publication order within the volume using a Base 36 numbering

system employing both numerals and letters. These two-number sets start with $00,01,02,03,04$, $05,06,07,08,09,0 A, 0 B \ldots$. OZ, followed by 10-1Z, 20-2Z, etc.

The CID Number appears on each page of the manuscript. The complete citation is used on the first page, and an abbreviated version on subsequent pages. 


\title{
Contents
}

\author{
$\checkmark$ Authors \\ vii Conference Committee
}

FEW PHOTON NONLINEARITIES AND HYBRID QUANTUM SYSTEMS

937707 Control of the cavity reflectivity using a single quantum dot spin (Invited Paper) [9377-6]

937708 Hybrid quantum nanophotonic devices for coupling to rare-earth ions [9377-7]

937709 Qubits, qutrits, and ququads stored in single photons from an atom-cavity system (Invited Paper) [9377-8]

$93770 \mathrm{~A}$ Coherent control of energy transfer in a quantum dot strongly coupled to a photonic crystal molecule [9377-9]

\section{QUANTUM TECHNOLOGIES WITH PHOTONS II}

9377 OG Time-bin entangled photon pairs from spontaneous parametric down-conversion pumped by a cw multi-mode diode laser (Invited Paper) [9377-15]

QUANTUM TECHNOLOGIES WITH PHOTONS III

9377 OK Preserving photon qubits in an unknown quantum state with Knill dynamical decoupling: towards an all optical quantum memory (Invited Paper) [9377-19]

9377 OL Entanglement assisted time-energy QKD employing Franson interferometers and cavity quantum electrodynamics (CQED) principles [9377-20]

\section{SOLID STATE QUANTUM MEMORIES AND PHOTONICS II}

9377 OY Laser written multiport quantum circuits [9377-33]

$9377 \mathrm{OZ}$ Toward remote ion-ion entanglement with barium [9377-38]

POSTER SESSION

937711 Eigenchannel decomposition for continuous-variable quantum key distribution [9377-35] 
937712 Abstract probabilistic CNOT gate model based on double encoding: study of the errors and physical realizability [9377-36]

937713 Quantum secure communication using a multi-photon tolerant protocol [9377-37] 


\title{
Authors
}

Numbers in the index correspond to the last two digits of the six-digit citation identifier (CID) article numbering system used in Proceedings of SPIE. The first four digits reflect the volume number. Base 36 numbering is employed for the last two digits and indicates the order of articles within the volume. Numbers start with 00, 01, 02, 03, 04, 05, 06, 07, 08, 09, 0A, 0B...0Z, followed by 10-1Z, 20-2Z, etc.

\author{
Attia, Moez, 12 \\ Auchter, Carolyn, $\mathrm{OZ}$ \\ Balouchi, Ashkan, OK \\ Barter, Oliver, 09 \\ Blinov, Boris B., $\mathrm{OZ}$ \\ Bose, Ranojoy, OA \\ Brown, Katherine L., OK \\ Cai, Tao, OA \\ Chaboyer, Zachary, OY \\ Chatta, Rihab, 12 \\ Chou, Chen-Kuan, $\mathrm{OZ}$ \\ Choudhury, Kaushik Roy, OA \\ Djordjevic, Ivan B., OL \\ Dowling, Jonathan P., OK \\ El Rifai, Mayssaa, 13 \\ Faraon, Andrei, 08 \\ Gueddana, Amor, 12 \\ Gupta, Manish K., OK \\ Gyongyosi, L., 11 \\ Hartz, Alex, 08 \\ Helt, L. G., OY \\ Holleczek, Annemarie, 09 \\ Imre, S., 11 \\ Kim, Hyochul, 07 \\ Kim, Yong-Su, OG \\ Kim, Yoon-Ho, OG \\ Kuhn, Axel, 09 \\ Kwon, Osung, OG \\ Langfahl-Klabes, Gunnar, 09 \\ Lee, Hwang, OK \\ Meany, Thomas, OY \\ Miyazono, Evan, 08 \\ Moulder, Todd A., OK \\ Mueller, Jason D., OK \\ Navarro, Erik J., OK \\ Noel, Thomas W., OZ \\ Park, Kwang-Kyoon, OG \\ Ra, Young-Sik, OG \\ Solomon, Glenn S., 07, 0A \\ Steel, M. J., OY \\ Sun, Shuo, 07 \\ Verma, Pramode K., 13 \\ Waks, Edo, 07, OA \\ Withford, Michael J., OY \\ Zhang, Yequn, $\mathrm{OL}$ \\ Zhong, Tian, 08
}


Proc. of SPIE Vol. $9377937701-6$

Downloaded From: https://www.spiedigitallibrary.org/conference-proceedings-of-spie on 26 Apr 2023 Terms of Use: https://www.spiedigitallibrary.org/terms-of-use 


\section{Conference Committee}

Symposium Chairs

David L. Andrews, University of East Anglia

(United Kingdom)

Alexei L. Glebov, OptiGrate Corporation (United States)

Symposium Co-chairs

Jean-Emmanuel Broquin, IMEP-LAHC (France)

Shibin Jiang, AdValve Photonics, Inc. (United States)

Program Track Chair

Zameer U. Hasan, Temple University (United States)

Conference Chairs

Zameer U. Hasan, Temple University (United States)

Philip R. Hemmer, Texas A\&M University (United States)

Hwang Lee, Louisiana State University (United States)

Alan L. Migdall, National Institute of Standards and Technology (United States)

Conference Program Committee

Dmitry Budker, University of California, Berkeley (United States)

Alan E. Craig, Montana State University (United States)

Jonathan P. Dowling, Lovisiana State University (United States)

Gurudev Dutt, University of Pittsburgh (United States)

Geoff J. Pryde, Griffith University (Australia)

Kai-Mei C. Fu, University of Washington (United States)

David H. Hughes, Air Force Research Laboratory (United States)

Fedor Jelezko, Universität Stuttgart (Germany)

Seth Lloyd, Massachusetts Institute of Technology (United States)

Marko Loncar, Harvard School of Engineering and Applied Sciences (United States)

Hideo Mabuchi, Stanford University (United States)

Frank A. Narducci, Naval Air Systems Command (United States)

Aleksander K. Rebane, Montana State University (United States)

Matthew J. Sellars, The Australian National University (Australia)

Selim M. Shahriar, Northwestern University (United States)

Alan E. Willner, The University of Southern California (United States)

Jörg Wrachtrup, Universität Stuttgart (Germany) 
Horace P. Yuen, Northwestern University (United States)

M. Suhail Zubairy, Texas A\&M University (United States)

\section{Session Chairs}

1 Non-Bleaching and Ultra-Small Fluorescent Probes I: Joint Session with Conference 9339

Ramesh Raghavachari, U.S. Food and Drug Administration (United States)

Philip R. Hemmer, Texas A\&M University (United States)

2 Non-Bleaching and Ultra-Small Fluorescent Probes II: Joint Session with Conference 9339

Ramesh Raghavachari, U.S. Food and Drug Administration (United States)

Philip R. Hemmer, Texas A\&M University (United States)

3 Few Photon Nonlinearities and Hybrid Quantum Systems

Alan L. Migdall, National Institute of Standards and Technology (United States)

4 Quantum Technologies with Photons I

Geoff J. Pryde, Griffith University (Australia)

5 Quantum Technologies with Photons II

Olivier Pfister, University of Virginia (United States)

6 Quantum Technologies with Photons III

Olivier Pfister, University of Virginia (United States)

$7 \quad$ Synthetic Gauge and Topological Order

Mohammad Hafezi, Joint Quantum Institute of National Institute of Standards and Technology and University of Maryland (United States)

8 Solid State Quantum Memories and Photonics I

Philip R. Hemmer, Texas A\&M University (United States)

9 Solid State Quantum Memories and Photonics II

Philip R. Hemmer, Texas A\&M University (United States) 